\title{
Body image dissatisfaction in adolescent girls in puberty
}

\author{
Insatisfação com a imagem corporal em adolescentes na puberdade \\ Insatisfacción con la imagen corporal en mujeres adolescentes en la pubertad
}

Received: 10/07/2021 | Reviewed: 10/16/2021 | Accept: 10/18/2021| Published: 10/20/2021

\author{
Gustavo André Borges \\ ORCID: https://orcid.org/0000-0003-3668-2325 \\ Universidade Estadual do Oeste do Paraná, Brazil \\ E -mail: gustavo.borges@unioeste.br \\ Pedro Pugliesi Abdalla \\ ORCID: https://orcid.org/0000-0002-7490-9466 \\ Universidade de São Paulo, Brazil \\ E -mail: pedroabdalla11@gmail.com \\ Dayane Cristina de Souza \\ ORCID: https://orcid.org/0000-0003-4552-6500 \\ Universidade Estadual do Oeste do Paraná, Brazil \\ E-mail: daynycs@gmail.com \\ Andreia Pelegrini \\ ORCID: https://orcid.org/0000-0001-8862-9636 \\ Universidade do Estado de Santa Catarina, Brazil \\ E -mail: pelegrini.andreia@gmail.com \\ Dalmo Roberto Lopes Machado \\ ORCID: https://orcid.org/0000-0001-7327-0800 \\ Universidade de São Paulo, Brazil \\ E-mail: dalmo@usp.br \\ João Fernando Christofoletti \\ ORCID: https://orcid.org/0000-0002-5902-1020 \\ Universidade Estadual do Oeste do Paraná, Brazil \\ E-mail: joao.christofoletti@unioeste.br
}

\begin{abstract}
The aim of this study was to analyze body image satisfaction among girls from different pubertal groups using two assessment instruments. The sample consisted of 82 adolescent girls, aged 11 to 14 years, divided into two groups: pre- and post-menarche. The Kakeshita's Body Image Scale (BIS) and Body Shape Questionnaire (BSQ) were used to assess body image dissatisfaction. For comparisons of anthropometric variables between pubertal groups, Student's ttest was used for independent samples. Comparisons between BMI classifications, body image satisfaction and desire for body image change were performed using chi-square and binomial tests for both groups. For the comparison between the instruments, the Kappa coefficient (K) was calculated. The results showed that, for BIS, more than $81 \%$ of adolescents showed dissatisfaction, being higher among adolescents in post-menarche. For BSQ, the prevalence of body dissatisfaction was lower, but the results did not confirm those previously observed. In both instruments (BIS and BSQ), there were no differences between groups. However, the study indicated a tendency for post-menarche girls to show greater dissatisfaction in relation to pre-menarche adolescents, while the instruments used do not show agreement in the results.
\end{abstract}

Keywords: Body image; Assessment; Adolescent; Menarche.

\section{Resumo}

O objetivo deste estudo foi analisar a satisfação com a imagem corporal de meninas de diferentes grupos puberais por meio de dois instrumentos de avaliação. A amostra foi constituída por 82 adolescentes do sexo feminino, com idades entre 11 e 14 anos, divididas em dois grupos: pré-menarca e pós-menarca. A escala de Imagem Corporal (IC) de Kakeshita e o Body Shape Questionnaire (BSQ) foram utilizados para avaliar a insatisfação com a imagem corporal. Para comparações das variáveis antropométricas entre os grupos púberes, o teste t de Student foi usado para amostras independentes. As comparações entre as classificações de IMC, satisfação com a imagem corporal e desejo de mudança na imagem corporal foram realizadas por meio dos testes qui-quadrado e binomial para ambos os grupos. Para a comparação entre os instrumentos, foi calculado o coeficiente Kappa (K). Para a IC, mais de $81 \%$ das adolescentes apresentaram insatisfação, sendo maior entre as adolescentes na pós-menarca. Para o BSQ, a prevalência de insatisfação corporal foi menor, mas os resultados não confirmaram os observados anteriormente. Em ambos os instrumentos (IC e BSQ), não houve diferenças entre os grupos. Porém, o estudo apontou tendência de meninas pósmenarca apresentarem maior insatisfação em relação às adolescentes pré-menarca, enquanto os instrumentos utilizados não apresentam concordância nos resultados.

Palavras-chave: Imagem corporal; Avaliação, Adolescentes. 


\begin{abstract}
Resumen
El objetivo del estudio fue analizar la satisfacción con la Imagen Corporal (IC) entre mujeres adolescentes de diferentes grupos púberes utilizando dos metodologías diferentes. La muestra estuvo constituida por adolescentes en la fase sin menarquia y con menarquia. Se utilizaron la Escala de Silueta (ES) del Kakeshita y el Body Shape questionnaire (BSQ) para evaluar la satisfacción con la imagen corporal. Para las comparaciones de las variables antropométricas entre los grupos puberales, se utilizó la prueba t de Student para muestras independientes. Las comparaciones entre las clasificaciones de IMC, la satisfacción con la imagen corporal y el deseo de cambiar la imagen corporal se realizaron mediante pruebas de chi-cuadrado y binomial para ambos grupos. Para la comparación entre los instrumentos se calculó el coeficiente Kappa (K). Como resultado, más del 81\% de las adolescentes mostró insatisfacción, siendo más elevado entre las adolescentes en la fase con menarquia. Con el uso de BSQ, la prevalencia de insatisfacción fue menor. En ambos instrumentos (ES y BSQ), no hubo diferencias entre grupos. El estudio indicó una tendencia de las mujeres adolescentes con menarquia a mostrar una mayor insatisfacción en relación con las adolescentes sin menarquia, mientras que los instrumentos utilizados no muestran concordancia en los resultados.
\end{abstract}

Palabras clave: Imagen Corporal; Evaluación, Adolescentes.

\title{
1. Introduction
}

Body Image (BI) can be understood as the figure of our body formed in our mind, being also the way in which the body is involved by immediate sensations and experiences (Schilder, 2010). The BI refers to a complex and multifaceted construct that involves perceptual, cognitive and behavioral aspects of the subject. The difference between the subjective perception of personal self-image in relation to the socially desired one is accompanied by the subject's own disapproval or dissatisfaction because it expresses the desire for a body different from the real one.

The adolescents value the body even more and are more susceptible to negative observations from overweight than when they are adults. The body image dissatisfaction is increasingly associated with the inability to master one's own body, which favors discrimination, stigmatization and even the occurrence of bullying (Gonçalves, 2016; Levandoski and Cardoso, 2013; Rech et al., 2013, Scutti et al., 2014). Thus, when young people are overweight, they carry a negative stigma in relation to people with the expected body shape (Mattos et al., 2012).

In this perspective, Conti et al. (2005) showed that body satisfaction in adolescent is characterized by multidimensional aspects, involving, to a greater or lesser extent, affectivity, cognition, perceptual-descriptive notion, body care (behavioral factor) and contextualization. That is, there are many factors that predispose adolescents to perceive their body, both positively and negatively, depending on the dimension they want to consider.

In Brazil, in recent years, studies were conducted with this issue among adolescents of both sexes, reporting very often a body dissatisfaction of this groups (Carraro et al., 2017; Ferreira et al., 2021; Glaner et al., 2013; Leite et al., 2014; Miranda et al., 2014a; Miranda et al., 2014b; Souza Pimentel et al., 2017), among girls, even if they are eutrophic (Nogueirade-Almeida et al., 2018). For many adolescent girls, to present overweight or obesity becomes a condition that makes them inferior in relation to peers due to the lack of adaptation and unwillingness to current beauty standards.

These results can be justified by the fact that, in adolescent girls, the physical changes derived from puberty are more evident than boys, due to the accentuated hormonal influences and the social 'burden' on the prettiness and body shape. It is, among the girls, a sensitive period in which the transformation of the body interferes with the perception of itself, which can lead to periods of anxiety, depression and dissatisfaction because it does not correspond to the idealized body shape (Campagna, 2005). In addition, in the period of childhood and adolescence, many issues make it difficult to understand the results, since, in this period of development and schooling, bullying, rejection, harassment and bodily stigmas in relation to excess weight and obesity itself are already a major social and affective problem (Puhl and Brownell, 2001).

Body image studies used different assessment tools and methodologies. Generally, when the body image assessment is treated from an attitudinal perspective, with a more subjective approach, seeking to understand above all the issues related to body weight, body image scales (BIS) are usually adopted. When there is a more perceptive, cognitive and/or behavioral 
approach, for to understand undesirable nutritional behaviors, the use of questionnaires is more relevant. The results of both instruments also reveal different prevalence of dissatisfaction. For example, while body image scale point to dissatisfaction, they are usually associated with body shape and weight and to seem transient or circumstantial. On the other hand, the score obtained in a certain questionnaire may indicate a body dissatisfaction in a more stable and durable way, since they try to evaluate a behavior observed in recent weeks and, in this case, seek to evaluate, many times, attitudes and perceptions about the body, not necessarily related only to satisfaction with body weight.

Thus, studies in Brazil using BIS among adolescents found frequent results of body dissatisfaction (Carraro et al., 2017; Cortez et al., 2013; De Carli et al., 2016; Ferreira et al., 2021; Fidelix et al., 2011; Glaner et al., 2013; Leite et al., 2014; Miranda et al., 2014a; Miranda et al., 2014b), especially when outcomes are associated with overweight or obesity, but few studies found these same results using questionnaires (Aerts et al., 2010; Andrade et al., 2010; De Toni et al., 2012; Miranda et al., 2014b; Paludo et al., 2011). The studies did not establish any tendency to change this condition in body dissatisfaction as adolescent girls mature and there are few studies that evaluate the convergence of outcomes when using different instruments at the same time in the same group of individuals.

Finally, assessment the body dissatisfaction from pubertal period can help to understand when this dissatisfaction becomes more pronounced among adolescent girls. Thus, the objective of this study was to identify the impact of menarche on body dissatisfaction in adolescents, considering two different evaluation instruments.

\section{Methodology}

This study is characterized by being descriptive, that aimed to describe the body dissatisfaction in adolescents in pubertal period, using menarche as an independent variable. To this end, an intentional sample of 82 adolescent girls, aged between 11 and 14 years, residents in Marechal Cândido Rondon - Paraná - Brazil. As an inclusion criterion, the girls had to be at least 11 years old and have a maximum age of 14.9 years; be voluntary; be present in the physical education classes on the day the questionnaire and anthropometric measurements are applied. By exclusion criteria, the adolescent did not to have their period on the day of the evaluation. For the conduct of the research, all ethical procedures were carried out in accordance with Declaration of Helsinki, including the informed consent obtained of the adolescent to participate in the research, with the preview authorization of the parents or guardians.

The weight and height were measured. The body mass index (BMI) was used to classify the nutritional status of girls and, we adopted the criteria for Brazilian children and adolescents by the Conde and Monteiro (2006) to classify underweight, eutrophy, overweight and obesity. For analysis purposes, just two groups were considered about nutritional status: low weight/eutrophy and overweight/obesity.

To assess body satisfaction, we used Kakeshita (2008) for children, a Brazilian BIS, which contains 11 body figures of adolescent, that represent a BMI variation between $12 \mathrm{~kg} / \mathrm{m}^{2}$ (thinness) to $29 \mathrm{~kg} / \mathrm{m}^{2}$ (obesity) with mean differences of 1.7 $\mathrm{kg} / \mathrm{m}^{2}$ between them. The data collection procedure consisted of asking each girl, individually, to indicate one of the body figures that best represented her body at that present time (current body). Then, were asked to indicate the figure her would like to have (ideal body). The body dissatisfaction was determined when there were differences between ideal body figure and current body figure. When the ideal body figure was lower than current body figure in the BIS, it was considered dissatisfied with the desire for reduction her body shape; when the body figures was opposite, dissatisfaction with the desire to increase her body shape was considered. When both body figures were the same in the body image scale, the body satisfaction was considered.

To expand and compare the diagnosis of dissatisfaction prevalence with BI, the Body Shape Questionnaire (BSQ) was applied, in its version translated in Brazil by Cordas and Castilho (2006) and validated for Brazilian girls (Conti et al., 2009). 
The BSQ consists of 34 questions, with six alternatives on the Likert scale, with the score distributed as follows: $\leq 80$ (no dissatisfaction); between 80 and 110 (slight dissatisfaction); between 111 and 140 (moderate dissatisfaction) and > 140 (serious dissatisfaction). In addition, for a better classification of the results obtained in BSQ, and to allow an adequate comparison with the results of BIS, it was decided to use an arbitrary and binary classification (satisfaction/dissatisfaction) based on the recommendation of Alves et al. (2008), considering only satisfied (BSQ $\leq 110)$ and dissatisfied (BSQ >110).

The pubertal stage was determined by the status quo method, in which the study participants were asked about the absence/presence of menstruation, separating the girls into two different groups: pre-menarche group (absence of menstruation); and post-menarche group (presence of menstruation).

To make the description of the sample, the standard deviation and the mean were used. For quantitative variables, differences between groups were tested using the t-test, for independent and unpaired samples. For qualitative or classification variables, intragroup differences were tested using the Binomial test and differences between groups using the Chi-square test $\left(\chi^{2}\right)$ to compare proportions. The adjusted residue $\left(\mathrm{R}_{\mathrm{aj}}\right)$ was calculated to find the specific differences between the groups. For the comparison between the concordance of the results between the instruments (BIS versus BSQ), the Kappa coefficient (K) was calculated to evaluate the Observed Concordance (OC) between the satisfaction/dissatisfaction classifications of the BI of girl. All analyses were performed using a previously established significance level $(\mathrm{p}<0.05)$.

\section{Results}

Of the 82 adolescents included in the study, $46(56.1 \%)$ reported the onset of menarche. The anthropometric and nutritional characteristics show that adolescents in the post-menarche group have higher mean values for the measured body variables $(\mathrm{p}<0.05)($ Table 1$)$.

Regarding the classification of the nutritional status of adolescent by group (pre- and post-menarche), the results showed that the majority of adolescents $(63.4 \% ; \mathrm{n}=51)$ were in the eutrophy range (BMI $\leq 25 \mathrm{~kg} / \mathrm{m}^{2}$ ). In girls in the premenarche group, there was a higher ratio of underweight/eutrophy $(n=29)$ in relation to overweight/obesity $(n=7)(p<0.001)$. Nutritional status frequencies were different when comparing groups $\left(\chi^{2}=6.732 ; p=0.009\right)$. There were fewer cases of underweight/eutrophy in the post-menarche group $(n=22)$ compared to the pre-menarche group $\left(n=29 ; R_{a j}=2.80 ; p<0.05\right)$. The pre-menarche group had fewer cases of overweight/obesity $(n=7)$ compared to post-menarche group $\left(n=22 ; R_{a j}=-2.80 ; p<0.05\right)$. Considering only the group of overweight/obese girl $(n=29)$, the comparison of body dissatisfaction $(n=21)$ among those in the post- $(\mathrm{n}=22$; dissatisfied=16 or $72.7 \%)$ and pre-menarche group $(\mathrm{n}=7$; dissatisfied=5 or $71.4 \%)$, showed no differences significant $\left(\chi^{2}<0.001 ; p>0.999\right)$. 
Table 1 - Mean values and standard deviation for height, weight, BMI and percentage frequency of nutritional status in the different pubertal group.

\begin{tabular}{|c|c|c|c|c|c|c|c|c|c|c|}
\hline \multirow{3}{*}{ Group } & \multirow{2}{*}{\multicolumn{2}{|c|}{$\begin{array}{l}\text { age } \\
\text { (years) }\end{array}$}} & \multicolumn{4}{|c|}{ Anthropometric variables } & \multirow{2}{*}{\multicolumn{2}{|c|}{$\begin{array}{l}\text { BMI } \\
\left(\mathrm{kg} / \mathrm{m}^{2}\right)\end{array}$}} & \multicolumn{2}{|c|}{ Nutritional State } \\
\hline & & & \multicolumn{2}{|l|}{$\begin{array}{l}\text { height } \\
(\mathrm{cm})\end{array}$} & \multicolumn{2}{|l|}{$\begin{array}{l}\text { weight } \\
(\mathrm{kg})\end{array}$} & & & $\begin{array}{l}\text { Underweight/ } \\
\text { Eutrophy }\end{array}$ & $\begin{array}{l}\text { Overweight/ } \\
\text { Obesity }\end{array}$ \\
\hline & Mean & sd & Mean & sd & Mean & $\mathrm{sd}$ & Mean & sd & $(\%)$ & $(\%)$ \\
\hline $\begin{array}{l}\text { All } \\
(n=82)\end{array}$ & 12.6 & 1.18 & 158 & 0.09 & 43.3 & 10.9 & 19.6 & 3.29 & 63.5 & $36.5^{\dagger}$ \\
\hline $\begin{array}{l}\text { Pre- menarche } \\
(\mathrm{n}=36)\end{array}$ & 11.8 & 0.99 & 153 & 0.07 & 43.6 & 10.4 & 18.5 & 3.77 & 80.6 & $19.4^{\mu ¥}$ \\
\hline $\begin{array}{l}\text { Post- menarche } \\
(\mathrm{n}=46)\end{array}$ & $13.2 *$ & 0.93 & $162 *$ & 0.07 & $53.8 *$ & 9.1 & $20.4^{*}$ & 2.62 & $50.0^{\beta}$ & 50.0 \\
\hline t-value & -6.576 & & -5.678 & & -4.777 & & -2.656 & & & \\
\hline${ }^{*} p$ & $<0.001$ & & $<0.001$ & & $<0.001$ & & 0.009 & & & \\
\hline
\end{tabular}

Note: BMI - Body mass index; cm - centimeter; kg - kilogram; $\mathrm{m}$ - meter: (\%): relative frequency.

${ }^{*} p<0.05$ vs. pre-menarche;

${ }^{\mu} p<0.001$ vs. underweight/eutrophy (without pre-menarche);

$\beta \mathrm{p}<0.05$ vs. underweight /eutrophy (without pre-menarche);

$¥ p<0.05$ vs. overweight/obesity (post-menarche);

${ }^{\dagger} p<0.05$ vs. underweight/eutrophy (all).

Source: Authors.

Table 2 shows the level of body dissatisfaction, through the use of BIS. The results are ordered into groups (pre- and post-menarche). As a result, more than $81 \%$ of adolescent women $(n=60)$ showed dissatisfaction $(\mathrm{p}<0.001)$. When these results are analyzed with respect to the pre- and post-menarche, $72 \%(n=28)$ of the pre-menarche group showed dissatisfaction $(\mathrm{p}=0.001)$, of which more than $80 \%(\mathrm{n}=27)$ wanted to reduce their figure in the scale. Among post-menarche group, this result was no different, since more than $89 \%(\mathrm{n}=32)$ were dissatisfied $(\mathrm{p}=0.004)$ and, among these, more than $97 \%$ ( $\mathrm{n}=30)$ wanted to reduce their figure in the scale. However, when comparing groups, there was no difference between the proportions of satisfaction and dissatisfaction $\left(\chi^{2}=0.670 ; \mathrm{p}=0.795\right)$.

Table 2 - Percentage values of dissatisfaction levels with BIS, in the different pubertal group.

\begin{tabular}{lllll}
\hline group & $\begin{array}{l}\text { Satisfied } \\
(\%)\end{array}$ & $\begin{array}{l}\text { Dissatisfied } \\
(\%)\end{array}$ & \multicolumn{2}{c}{ Dissatisfaction with desire } \\
\cline { 4 - 5 } $\begin{array}{l}\text { All } \\
(\mathrm{n}=82)\end{array}$ & 18.3 & $81.7^{\dagger}$ & Reduction $(\%)$ & Increase $(\%)$ \\
Pre- menarche $(\mathrm{n}=36)$ & 27.8 & $72.2^{*}$ & $91.0^{\beta}$ & 9.0 \\
Post- menarche $(\mathrm{n}=46)$ & 10.9 & $89.1^{\ddagger}$ & $80.8^{\ddagger}$ & 19.2 \\
\hline
\end{tabular}

${ }^{\dagger} \mathrm{p}<0.001$ vs. satisfaction (all groups);

${ }^{*} \mathrm{p}<0.05$ vs. satisfaction (pre-menarche group);

${ }^{¥} \mathrm{p}<0.05$ vs. satisfaction (post-menarche group)

${ }_{\mathrm{p}} \mathrm{p}<0.001 \mathrm{vs}$. increase (all groups);

${ }_{\mathrm{p}}^{\mathrm{p}}<0.001 \mathrm{vs.}$ increase (pre-menarche group);

$\epsilon_{\mathrm{p}}<0.001$ vs. increase (post-menarche group).

Source: Authors.

In the intragroup comparison, dissatisfaction prevails, considering all girls $(\mathrm{p}<0.001)$, in the pre-menarche group $(\mathrm{p}=0.001)$ and in the post-menarche group $(\mathrm{p}=0.004)$. In the comparison between groups, there were no differences in the frequencies of satisfaction (pre- vs. post-menarche), nor of dissatisfaction (pre- vs. post-menarche) $\left(\chi^{2}=0.670 ; \mathrm{p}=0.795\right)$. When analyzing the group of girls dissatisfied with their silhouette $(n=60)$, there was a greater predominance of the desire to reduce 
$(\mathrm{n}=57)$ compared to the desire to increase her figures $(\mathrm{n}=3)(\mathrm{p}<0.001)$. The same trend was confirmed when analyzed by group, pre-menarche (reduction: $n=27$ versus increase: $n=1 ; p<0.001$ ) and post-menarche (reduction: $n=30$ versus increase: $\mathrm{n}=2 ; \mathrm{p}<0.001$ ). In the comparison between the groups, there were no differences in the frequencies of body dissatisfaction with the desire to reduce or increase the body figure in the scale (pre- vs post-menarche) $\left(\chi^{2}<0.001 ; p=0.999\right)$.

Table 3 presents the results of body dissatisfaction, verified by BSQ. The post-menarche group had a higher prevalence of body dissatisfaction compared to the adolescents in the pre-menarche $(\mathrm{t}=-3.428 ; \mathrm{p}=0.001)$. Significant differences were found when comparing the proportions of each classification between the groups $\left(\chi^{2}=12.958 ; p=0.005\right)$. For the "no dissatisfaction" classification, there were more cases of adolescent in the pre-menarche $\left(\mathrm{R}_{\mathrm{aj}}=2.7 ; \mathrm{p}<0.05\right)$. There was no difference in the number of cases between the groups for the classifications of "slight dissatisfaction" and "moderate dissatisfaction". However, the classification of "serious dissatisfaction" was more frequent in the post-menarche group $\left(\mathrm{R}_{\mathrm{aj}}=-\right.$ $2.3 ; \mathrm{p}<0.05)$.

The BSQ indicated that $50 \%$ of girls showed no concern about their high frequency (Table 3). However, when the absence/presence of menarche was considered, there was a decrease in the classification of "no dissatisfaction" (66.7\% vs $37.0 \%$, in girls pre- and post- menarche, respectively). It could also be observed that among pre-menarche group there was no "serious dissatisfaction", while in girl's post-menarche this condition occurred in $13 \%$ of them.

Table 3 - Mean values and percentages of the classification of the BSQ, in in the different pubertal group.

\begin{tabular}{lllllllll}
\hline Group & Mean & sd & $\begin{array}{l}\text { No } \\
\text { dissatisfaction } \\
(\%)\end{array}$ & $\begin{array}{l}\text { Slight } \\
\text { dissatisfaction } \\
(\%)\end{array}$ & $\begin{array}{l}\text { Moderate } \\
\text { dissatisfaction } \\
(\%)\end{array}$ & $\begin{array}{l}\text { Serious } \\
\text { dissatisfaction } \\
(\%)\end{array}$ & $\begin{array}{l}\text { BSQ } \\
\text { Scores }>110 \\
\%(\mathrm{n})\end{array}$ \\
\hline $\begin{array}{l}\text { All } \\
(\mathrm{n}=82)\end{array}$ & 88.8 & 35.5 & 50.0 & 23.2 & 19.5 & 7.3 & 26.8 & $(22)$ \\
$\begin{array}{l}\text { Pre- } \\
\begin{array}{l}\text { menarche } \\
(\mathrm{n}=36)\end{array}\end{array}$ & 74.5 & 28.2 & $66.7^{\ddagger}$ & 22.2 & 11.1 & - & 11.1 & $(4)$ \\
\begin{tabular}{l}
$\begin{array}{l}\text { Post- menarche } \\
(\mathrm{n}=46)\end{array}$ \\
\hline
\end{tabular} & $99.9^{*}$ & 36.8 & 37.0 & 23.9 & 26.1 & ${ }^{\ddagger} 13.0$ & 39.1 & $(18)$ \\
\hline
\end{tabular}

$* \mathrm{p}<0.05$ vs. mean BSQ (pre-menarche);

${ }_{\mathrm{p}}^{\mathrm{p}}<0.05$ vs. No dissatisfaction (post-menarche);

${ }^{£} \mathrm{p}<0.05$ vs. Serious dissatisfaction (pre-menarche).

Source: Authors.

When we tried to test the concordance of the two instruments for the evaluation of body dissatisfaction in pre- and post-menarche groups, the results show that there was no agreement between the classifications observed by the BIS and the BSQ (scores >110). Even when analyzed by post-menarche group, the disagreement between the instruments remained (Table 4).

Table 4 - Observed agreement between the ratings of satisfaction/dissatisfaction in the different pubertal group performed for the BIS and the BSQ, by the criteria of Alves et al. (2008).

\begin{tabular}{llllll}
\hline Group & $\mathrm{N}$ & Concordance & kappa & $p$ & Interpretation \\
\hline All & 80 & $25(31.2 \%)$ & -0.112 & 0.107 & no agreement \\
Pre- menarche & 36 & $8(22.3 \%)$ & -0.086 & 0.156 & no agreement \\
Post- menarche & 44 & $17(38.6 \%)$ & -0.112 & 0.343 & no agreement \\
\hline
\end{tabular}

Source: Authors. 


\section{Discussion}

Regarding the results for the variables related to the nutritional status of adolescents in the present study, we observed that the mean BMI values for groups of adolescent women pre- and post-menarche are very similar to those found in different studies with Brazilian girls (Oliveira Antônio et al., 2012; Santos et al., 2012)

When we analyzed the results of dissatisfaction with BIS, we observed that adolescents in both groups had a high prevalence of dissatisfaction, with an evident desire to reduce her body shape. This concern for weight during adolescence was already identified by Campagna (2005), when interviewing adolescent women in the period pre- and post-menarche, being showed great concern for height and weight. Concern for body mass was more prominent, as they felt less "pressured" when their weight was within "normal" (eutrophic).

About this, some studies that assessed the body dissatisfaction of children and adolescents through BSQ, found very similar overall results, with little or no concern for BIS (De Toni et al., 2012; Paludo et al., 2011; Andrade et al., 2010). These studies also showed that, in the post-puberty period, the adolescents reached more expressive levels of dissatisfaction than children.

In the same direction, Miranda et al. (2014b), used BSQ and BIS in schoolchildren of both sexes (10 to 21 years), with the aim to characterize and evaluate changes in body satisfaction throughout childhood and adolescence. The BSQ results showed that most of students $(71.1 \%)$ were satisfied with BI, while $28.9 \%$ showed some dissatisfaction, noting that the most critical period was in early adolescence (10 to 13 years). On the other hand, when the same authors evaluated body dissatisfaction with BIS, they observed an opposite result. In other words, among the adolescents analyzed, 78.9\% were unsatisfied, being that girls were more dissatisfactions than boys, in any age group analyzed.

The use of the BSQ to assess body satisfaction in girls indicates that its results may be underestimated in relation to BIS. These differences can be explained because the questionnaires present questions that deal with both the perception of body size/shape and the negative feelings that the body produces in individuals, differing substantially in the diagnosis of body dissatisfaction based solely on the combination of current and ideal body figures.

The differences found in the present study between the two instruments show that BSQ, despite having been validated for Brazilian adolescents (Conti et al., 2009), seems to be characterized, in fact, by more adequately evaluating eating disorders, because, according to Cooper et al. (1987), BSQ was conceived as a questionnaire on concerns about body shape, a well-recognized characteristic in eating disorders. In relation to the present study, where most the girls were in eutrophic conditions, the questionnaire did not seem to show serious dissatisfaction, but the results were more expressive when we used an BIS, since the girls themselves demonstrated the desire to decrease their body figure in a scale.

In addition, for the girls, the Likert scale adopted in the BSQ, with six alternatives, the set of 34 questions seemed to leave the questionnaire more exhausting and with very similar answers, making it difficult for this age group to adequately differentiate their answers, often underestimating the feeling observed in each question, which in BIS does not seem to have happened, since this method only distinguish a desire to have body figures different into the scale.

Thus, regardless of the use of different instruments to assess satisfaction with $\mathrm{BI}$, the results only corroborate the hypothesis that, in the transition from childhood to adolescence, the girls show greater body dissatisfaction, especially after menstruation. This phenomenon occurs because after menstruation begin to worry about a body that changes rapidly in size and shape, while they are interested in new affective relationships. For Bretas et al. (2012), adolescents realize that they will begin to have more interesting and attractive bodies, but above all, that they are also interested in attractive and good look bodies.

In the same direction, Campagna and Souza (2006) sought to understand the change of the body during adolescence, they presented a story of a girl who affirms that adolescence "is a time of changes in relation to everything [...], you begin to 
think about the future, to have boyfriends" (p. 19). This report highlights an important dimension about the concern for the body among adolescent at the beginning of puberty.

Therefore, during adolescence, the numerous bodily changes resulting from puberty seem to trigger a bodily discomfort, a feeling of strangeness, which leads to the loss of the child's knew body shape (Dias, 2000) by a still uncertain image of a body that will become an adult.

In the case of body image, this uncertainty about body changes can lead to dissatisfaction with the body, even when the body is in the normal condition of its nutritional status. That is, according to Wertheim et al. (2009), peers and friends have an important influence on the group's body shape, mainly on girls' satisfaction with your weight. For these authors, young people's social networks share their perceptions and attitudes towards the body in a way that they are always attentive and value weight control and diet, a huge socio-affective control that is strongly related to the frequent concerns about overweight among girls during adolescence.

In our society, particularly in a tropical country, like Brazil, where body shapes gain even more social and affective relevance, there is an overvaluation in the body shape and a cult of thinness. Not having "perfect measurements" can make people easily susceptible to dissatisfaction with their own bodies, especially during adolescence. This may be the case for many adolescents in the present study.

\section{Conclusion}

In general, we can conclude that the adolescents, in the different groups of puberty, showed body image dissatisfaction, regardless of whether they are in eutrophic conditions. In the present study, the adolescents menarched showed no more significant differences in body dissatisfaction when compared to the group of girls with no menarche. However, they revealed that body image dissatisfaction may be more significant after menarche. Regarding the use of different instruments and methodologies, such as BIS or questionnaires, like BSQ, the results showed that the BIS show greater eloquence in demonstrating a body image dissatisfaction, when this is more associated exclusively with the issue of body weight, than when questionnaires are used. The BSQ, on the other hand, highlights broader issues about body dissatisfaction, and not a single preoccupation with shape and body weight.

The results of the two instruments were compared, they revealed little agreement with each other, showing that the use of bis revealed more expressive results in body weight dissatisfaction than the use of questionnaires, principally in the post-menarche group. So, for the girls in both pubertal groups, the bis tends to reveal a "momentary" dissatisfaction with body weight, since also it is associated with BMI, while the questionnaires seek to understand whether adolescents present behaviors that may reflect the appearance of eating disorders and does not seek to evaluate a body image as a mere concern with inadequate body weight.

\section{References}

Aerts, D., Madeira, R. R., \& Zart, V. B. (2010). Imagem corporal de adolescentes escolares em Gravataí-RS. Epidemiologia e Serviços de Saúde, 19(3), 283291. https://dx.doi.org/10.5123/S1679-49742010000300010

Alves, E., Vasconcelos, F. A. G., Calvo, M. C. M. \& Neves, J. (2008). Prevalência de sintomas de anorexia nervosa e insatisfação com a imagem corporal em adolescentes do sexo feminino do Município de Florianópolis, Santa Catarina, Brazil. Cadernos de Saúde Pública, 24, 503-512. https://doi.org/10.1590/S0102-311X2008000300004

Andrade, M. R. M., Amaral, A.C. S., \& Ferreira, M. E.C. (2010). A cultura do corpo ideal: Prevalência de Insatisfação Corporal entre Adolescentes. Revista Psicologia em Pesquisa, 4(1) 24-30. https://periodicos.ufjf.br/index.php/psicologiaempesquisa/article/download/23606/13087 
Campagna, V. N., \& Souza, A. S. L. D. (2006). Corpo e imagem corporal no início da adolescência feminina. Boletim de Psicologia, 56(124), 9-35. http://pepsic.bvsalud.org/pdf/bolpsi/v56n124/v56n124a03.pdf

Carraro, F., Rech, R. R., Frata, B., Halpern, R., Zanol, F., Colognese, A. R., .., \& Fonseca, G. M. M. (2017). Insatisfação com a imagem corporal em adolescentes na cidade de Farroupilha, RS. Revista da AMRIGS, 61(1), https://web.archive.org/web/20180412033303id_/http://www.amrigs.com.br/revista/61-01/02_1697_Revista\%20AMRIGS.pdf

Castilho, S. D., \& Barras Filho, A. A. (2000). Crescimento com menarca. Arquivos Brasileiros de Endocrinologia \& Metabologia, 44(3), 195-204. http://dx.doi.org/10.1590/S0004-27302000000300003

Conde, W. L., \& Monteiro, C. A. (2006). Valores críticos do índice de massa corporal para classificação do estado nutricional de crianças e adolescentes brasileiros. Jornal de Pediatria, 82(4), 266-272. http://dx.doi.org/10.2223/JPED.1492

Conti, M. A., Gambardella, A. M., \& Frutuoso, M. F. (2005). Insatisfação com a imagem corporal em adolescentes e sua relação com a maturação sexual. Journal of Human Growth and Development, 15(2), 36-44. https://doi.org/10.7322/jhgd.19756

Conti, M. A., Cordás, T. A., \& Latorre, M. D. R. D. D. O. (2009). A study of the validity and reliability of the Brazilian version of the Body Shape Questionnaire (BSQ) among adolescents. Revista Brasileira de Saúde Materno Infantil, 9(3), 331-338. https://doi.org/10.1590/S1519-38292009000300012

Cooper, P. J., Taylor, M. J., Cooper, Z., \& Fairbum, C. G. (1987). The development and validation of the Body Shape Questionnaire. International Journal of Eating Disorders, 6(4), 485-494. https://doi.org/10.1002/1098-108X(198707)6:4<485::AID-EAT2260060405>3.0.CO;2-O

De Carli, P. B., Abdalla, P. P., Machado, D. R. L., \& Borges, G. A. (2016). Insatisfação com a imagem corporal de meninas de 11 a 14 anos de idade. Caderno de Educação Física e Esporte, 14(1), 59-68. http://saber.unioeste.br/index.php/cadernoedfisica/article/view/14975/11708

De Toni, V., Gavineski, I., Migon, P., Finato, S., Rech, R., \& Halpern, R. (2012). Insatisfação com a Imagem Corporal em adolescentes de Escolas Públicas de Caxias do Sul-RS. Revista Brasileira de Ciências da Saúde, 16(2), 187-94. https://doi.org/10.4034/RBCS.2012.16.02.10

Dias, S. (2000). A inquietante estranheza do corpo e o diagnóstico na adolescência. Psychology USP, 11(1), 119-135. https://doi.org/10.1590/S010365642000000100008

Ferreira, L. de S., Rodrigues, T. C., Lima, V. S. de, Bezerra, A. N., Albuquerque, N. V., \& Pereira, C. P. (2021). Percepção da imagem corporal em adolescentes e a relação com seu estado nutricional. Research, Society and Development, 10(1), e8710111484. https://doi.org/10.33448/rsd-v10i1.11484

Fidelix, Y. L., Silva, D. A. S., Pelegrini, A., Silva, A. F. D., \& Petroski, E. L. (2011). Insatisfação com a imagem corporal em adolescentes de uma cidade de pequeno porte: associação com sexo, idade e zona de domicílio. Revista Brasileira de Cineantropometria e Desempenho Humano, 13(3), $202-7$. https://doi.org/10.5007/1980-0037.2011v13n3p202

Glaner, M. F., Pelegrini, A., Cordoba, C. O., \& Pozzobon, M. E. (2013). Associação entre insatisfação com a imagem corporal e indicadores antropométricos em adolescentes. Revista Brasileira de Educação Física e Esporte, 27(1), 129-136. https://doi.org/10.1590/S1807-55092013000100013

Gonçalves, M. L.M. D.C. (2016). Bullying e imagem corporal nos adolescentes (Tese de Doutorado, Universidade do Minho). http://hdl.handle.net/1822/43081

Kakeshita, I. S. (2008). Adaptação e validação de escalas de silhuetas para crianças e adultos brasileiros (Tese de Doutorado, Universidade de São Paulo). https://doi.org/10.11606/T.59.2008.tde-25052008-170240

Leite, A. C. B., Ferrazzi, N. B., Mezadri, T., \& Höfelmann, D. A. (2014). Insatisfação corporal em escolares de uma cidade do Sul do Brasil. Journal of Human Growth and Development, 24(1), 54-61. https://doi.org/10.7322/jhgd.72154

Levandoski, G., \& Cardoso, F. L. (2013). Imagem corporal e status social de estudantes brasileiros envolvidos em bullying. Revista Latinoamericana de Psicología, 45(1), 135-145. https://www.redalyc.org/pdf/805/80526356006.pdf

Mattos, R. da S., Perfeito, R., Carvalho, M. C. D. V. S., \& Retondar, J. (2012). Obesidade e bullying na infância e adolescência: o stigma da gordura. Demetra: Alimentação, Nutrição \& Saúde, 7(2), 71-84. https://doi.org/10.12957/demetra.2012.3330

Miranda, V. P. N., Conti, M. A., Bastos, R. R., Laus, M. F., Almeida, S. D. S., \& Ferreira, M. E.C. (2014). Imagem corporal de adolescentes de cidades rurais. Ciência \& Saúde Coletiva, 19,1791-1801. https://doi.org/10.1590/1413-81232014196.14082013

Miranda, V. P. N., Conti, M. A., Carvalho, P. H.B. D., Bastos, R. R., \& Ferreira, M. E.C. (2014). Imagem corporal em diferentes períodos da adolescência. Revista Paulista de Pediatria, 32(1), 63-69. http://dx.doi.org/10.1590/S0103-05822014000100011

Oliveira Antônio, A., da Silva, C. D., de Oliveira, M. L., Silva, A. C., \& Carneiro-Júnior, M. A. (2012). Comparação do perfil antropométrico e desempenho físico entre escolares antes e após a menarca. Brazilian Journal of Biomotricity, 6(1), 11-17. https://www.redalyc.org/pdf/930/93023652002.pdf

Paludo, A. C., Pelegrini, A., Grespan, F., Caldeira, A. S., Madureira, A. S., \& Serassuelo Junior, H. (2011). Insatisfação com a imagem corporal em adolescentes: prevalência e associação com o estado nutricional. ConScientiae Saúde, 10(1), 143-149. https://www.redalyc.org/pdf/929/92917188018.pdf

Puhl, R., \& Brownell, K. D. (2001). Bias, discrimination, and obesity. Obesity Research, 9(12), 788-805. https://doi.org/10.1038/oby.2001.108

Rech, R. R., Halpern, R., Tedesco, A., \& Santos, D. F. (2013). Prevalence and characteristics of victims and perpetrators of bullying. Jornal de Pediatria, 89(2), 164-170. http://dx.doi.org/10.1016/j.jped.2013.03.006

Santos, M. L. B. dos, Monteiro, L. A.C., Ferreira, M. E. C., de Sousa, M. D. S. C., de Oliveira Damasceno, V., Miranda, H., \& da Silva Novaes, J. (2012). Níveis de satisfação da imagem corporal de adolescentes antes e depois da menarca. Manual Therapy, 10(49), 148-154. https://www.researchgate.net/publication/285925519_Niveis_de_satisfacao_da_imagem_corporal_de_adolescentes_antes_e_depois_da_menarca 
Research, Society and Development, v. 10, n. 13, e517101321524, 2021

(CC BY 4.0) | ISSN 2525-3409 | DOI: http://dx.doi.org/10.33448/rsd-v10i13.21524

Schilder, P. (2000). A imagem do corpo: as energias construtivas da psique. 2 ed. Martins Fontes.

Scutti, C. S., Seo, G. Y., Amadeu, R. S., \& Sampaio, R. F. (2014). O enfrentamento do adolescente obeso: a insatisfação com a imagem corporal e o bullying. Revista da Faculdade de Ciências Médicas de Sorocaba, 16(3), 130-133. https://revistas.pucsp.br/index.php/RFCMS/article/view/15188/pdf

Souza Pimentel, Z. N. de, Castro Aerts, D. R. G. de, Jacob, M. H. V. M., Alves, G. G., Câmara, S. G., \& Palazzo, L. (2017). Preocupação com a imagem corporal e fatores associados em adolescentes do ensino público em um município da Amazônia. Adolescencia e Saude, 14(2), 94-103. https://cdn.publisher.gn1.link/adolescenciaesaude.com/pdf/v14n2a11.pdf

Wertheim, E. H., Paxton, S. J., \& Blaney, S. (2009). Body image in girls. In Smolak, L., \& Thompson, J. K. (Orgs.), Body image, eating disorders, and obesity in youth: Assessment, prevention, and treatment (2nd ed.) (47-76). American Psychological Association. http://dx.doi.org/10.1037/11860-003 